\title{
Issues of Methodological Pluralism in Management Science: The Case of Non-Profit Marketing Concept
}

\author{
Edouard V. Novatorov \\ Department of management, National Research University,Higher School of Economics, Russia \\ *Corresponding Author: enova@mail.ru
}

Copyright (C) 2013 Horizon Research Publishing. All rights reserved.

\begin{abstract}
The paper discusses and suggests alternative methodological paradigms to approach the problem "marketing to nonmarketers". First, the paper describes the issue of "marketing to nonmarketers" and proposes the purpose of this article. Then it presents methodological issues in management science and describes four major research paradigms: the logico-positivist/empiricist paradigm, constructivism, critical theory, and the pluralist paradigm. Finally, it concludes that pluralist approach will benefit and enrich both the management science and non-profit field. Using as a case methodological development of nonprofit marketing concept and followed controversy over "marketing to nonmarketers" controversy paper traces evolution of the issue in context of research methodology. Paper concludes that traditional approach it based on logico-positivist paradigm. Article suggests adaptation of alternative methodological approaches and research paradigms to approach the problem "marketing to nonmarketers".
\end{abstract}

Keywords Nonprofit Marketing, Research Methodology, Epistemology, Ontology, Post Positivism, Pluralist Paradigm

\section{The Emergence of Marketing in the Public and Nonprofit Sectors}

Interest among public administrators in the application of marketing tools to public sector services also emerged from the tax revolt of the late 1970s and early 1980s. With the shrinkage and withdrawal of grants from federal and state governments, municipalities were confronted with the issue of how to satisfy the growing expectations of taxpayers in a milieu of reduced financial resources. During this period of financial scarcity, the public administration literature witnessed an attempt to rethink the nature of public sector management through the active importation and borrowing of private sector techniques. Several commentators labeled this process of importation as integration of public and private sector management or in briefer terms "managerialism" (Graham, 1995; Murray, 1975; Walsh, 1994). Marketing in the public sector was part of the managerialism movement (Mansfield, 2011; Miller, 2013).

\section{Marketing to Nonmarketers Controversy}

Although the concept of marketing in the nonprofit and public sectors was initially criticized in the marketing literature as confusing (Luck, 1969; 1974), it eventually became widely embraced by marketing scholars and consultants (Nickels, 1974). Lovelock and Weinberg (1978) noted that by the end of the 1970s there was no longer any serious controversy among marketing scholars about the appropriateness of the concept for the public and nonprofit sectors. However, despite this apparent agreement among marketing academics, public administrators and academics in public administration and nonprofit areas have not unanimously embraced the utility of the concept of non-profit and public sector marketing (Mansfield, 2011).

During the subsequent three decades the "marketing to nonmarketers" problem in the context of the public sector, has split public administrators into two camps comprised of its supporters and opponents. Thus, Roberto (1991, p. 81), an active proponent of marketing, observed: "Marketing's recent and growing participation in public sector management has received a bipolar love-hate evaluation."

Those commentators, who are critical of marketing, do partially recognize the need of public administrators to adopt new management techniques to deal with the prevailing environment of «less-government-more-user-fees». However, they refer to the application of marketing principles within the nonprofit and public administration fields as "confusion compounded", "an inappropriate model", "intellectualization", "absurd", "the megalomaniac marketing supremacy syndrome", and "a dramatic imitation" of social relationships (Arndt, 1978; Capon and Mauser, 1982; Luck, 1974; Loveday, 1991; Monieson, 1988; Vanden Heede and Pelican, 1995). The opponents' position was perhaps best articulated by Walsh $(1994$, p. 68) who suggested the need to redefine public marketing "...if it is to 
be specifically public service marketing rather a pale imitation of a private sector approach within the public sector."

In contrast to the position of marketing opponents, supportive commentators refer to its use as "a comprehensive strategy for effecting social change" with "unique concepts and techniques" which are "coming of age" and are merely "misunderstood" (Leathar and Hastings, 1987; Lovelock and Weinberg, 1978; Hastings and Haywood, 1991; Roberto, 1991; Miller, 2013). Ironically, the ultimate goal of marketing proponents was essentially the same as that of its opponents--to increase the effectiveness and responsiveness of public organizations in a changed financial environment. The essence of the difference in opinions appears to relate to the means by which this commonly recognized goal should be achieved.

The "marketing to nonmarketers" issue has wide geographic and disciplinary scope. It can be found in such diverse disciplines as political science, arts and culture, health promotion, fundraising, and nutrition education. The geography of the debates ranges from the Republics of the former Soviet Union, across Europe and Scandinavia, through North America, to New Zealand and Australia.

The major assumptions of this article is that "marketing to nonmarketers" problem emerged from controversial broadened marketing proposition and its authors used poor and ideologically biased reductionist methodology. The purpose of this article is to discuss and suggest alternative methodological paradigms to approach the problem.

\section{Methodological Issues in Social Sciences}

An ongoing and pervasive debate among social scientists during the last two decades of the twentieth century has been taking place between naturalists, antinaturalists, critical theorists, and pluralists regarding the issue of how social phenomena should be studied (Martin and McIntyre, 1997). Naturalists argue that the study of social and of natural phenomena should be approached in the same way using objectivist epistemology, ontological belief in realism, and experimental methodology. Antinaturalists disagree with naturalists, believing that differences between natural and social phenomena mandate that a different approach should be used to study social phenomena. Contrary to "hard" natural sciences, the "soft" social science approach should be based on subjectivist epistemology, relativist ontology, and qualitative methodology. Critical theorists partially agree with naturalists and antinaturalists, accepting naturalists' methodology and antinaturalists' subjectivity. At the same time, critical theorists partially disagree with naturalists' and antinaturalists' approaches, rejecting naturalists' ontological beliefs in relativity of truth and naturalists' epistemological belief in the objectivity of a researcher. Finally, pluralists advocate equality of all approaches arguing that all these approaches have a right to co-exist because they are generating different types of knowledge, motivated by various research interests, and guided by distinct scientific ideals.

Different responses to the issue of how social phenomena should be studied have shaped alternative philosophical orientations in the contemporary philosophy of social science. These diverse philosophical orientations are founded on dissimilar assumptions about the nature of reality (ontology), the nature of relationships between the knower and the known (epistemology), and approved ways to conduct investigations (methodology). Combinations of these ontological, epistemological, and methodological assumptions are often referred to as alternative research paradigms. Paradigms predetermine a specific approach to the study of social phenomena (Guba and Lincoln, 1994). Four major research paradigms are widely recognized by researchers: (1) the logico-positivist/empiricist paradigm; (2) constructivism; (3) critical theory; and (4) the pluralist paradigm (Braybrooke, 1987; Guba and Lincoln, 1994; Gultung 1990; Little, 1991).

\subsection{Logico-Positivist/Empiricist Paradigm}

Advocates of the logico-positivist/empiricist paradigm, which Martin and McIntyre (1997, p. 533) identified as being derived from the naturalist approach, suggest that the study of social phenomena by social scientists should be approached in the same way as the study of natural phenomena are approached by those working in the natural sciences. They perceive the goals of science to be prediction, control, and nomological explanation. The task of the researcher is to uncover and formulate time-and-context free cause-effect laws, which are often expressed in rigorous mathematical terms. Although there are several schools of thoughts within the naturalistic approach (e.g. empiricism, falsificationism, postpositivism, etc.), there are common denominators among them. These include: (1) the ontological belief that apprehensible reality exists and is governed by invariant laws (realism); (2) the epistemological assumption that subjective values of the researcher can be excised from the research process through proper research design, sample choice, and validity and reliability checks (objectivism); and (3) the methodological approach that relies heavily on quantitative methods, statistical measures, and empirical verifications of propositional hypotheses (experimental methodology) (Arndt, 1985; Guba and Lincoln, 1994; Lincoln and Guba, 1985; Martin and McIntyre, 1997).

Arndt (1985) notes that although the origin of the naturalist approach is attributed to the French philosopher Auguste Comte who defended positivism as a scientific method, naturalism is part of the Anglo-American philosophy of science tradition. It is the most dominant orientation in modern American social science thought, which includes the park and recreation and the marketing fields (Arndt 1985; Guba and Lincoln, 1994). This hegemony is maintained by pressures to conform through the 
narrow empiricist perspective which is characteristic of most $\mathrm{Ph} . \mathrm{D}$. programs; the prevalence of this model in most articles in major journals; preferred access to funding by proposals using this model; and the conservative approach adopted by promotion and tenure committees (Guba and Lincoln, 1994). Arndt (1985, p. 19) noted that each new generation of researchers is "born into" the naturalist approach, rather than consciously selecting it, and if a dissident researcher decides to pursue a different approach then he or she would likely be condemned ".... to suffer the slow burnout of never emerging from the journals' revision purgatories." In the marketing literature, the naturalist approach has been rigorously defended and advocated by Hunt (1983).

\subsection{Constructivism}

A major tenet of the constructivist paradigm is a shift from the ontological belief that reality exists and that it is driven by eternal laws, to the ontological assumption that reality is more or less comprised of informed multiple constructions held by social actors and that these constructions are alterable. While Martin and McIntyre (1997) refer to the constructivist orientation as an antinaturalist approach, Morrow and Brown (1994) designate the same orientation as a humanistic orientation in the social sciences. Antinaturalists or humanists contend that there are substantial differences in the subject matter of the natural and social sciences, which demand there be different approaches to the study of social and natural phenomena. Antinaturalists deny nomological explanations and argue that causality, generalizations, predictions, and mathematical laws have little or no importance in the social sciences.

According to constructivists, social phenomena are intrinsically meaningful. They are shaped by the mental constructions that social actors hold and attach to them. Hence, the antinaturalist approach suggests that the goal of science should be unraveling, understanding and reconstructing the meanings held by individuals or groups (relativism) and the method of science should be interpretation (hermeneutics) from the point of view of the social actor (verstehen). Constructivism challenges the distinction between ontology and epistemology, assuming an interactive linkage of the researcher and the object of investigation (subjectivism) so that the findings of an inquiry are themselves a literal creation or construction of the inquiry process. Historical roots of constructivism derive from the literary interpretation and criticism of poets practiced in ancient Greece and the religious exegesis--an attempt to interpret disputed or hidden meanings of authoritative religious texts. Modern constructivism has been influenced by phenomenological and ethnomethodological traditions and has had a strong effect on European philosophy (Bleicher 1980; Little 1991; Martin and McIntyre 1997; Rabinow and Sullivan 1987). According to Monieson (1988), in the marketing literature the constructivist orientation is rather underdeveloped and the hermeneutic ideal is only beginning to be appreciated (Hirschman 1986).

\subsection{Critical Theory}

Critical theory occupies a niche in social philosophy that is dissimilar to both the naturalist and the antinaturalist approaches. In terms of the nature of reality, it seems closer to positivism since it also accepts realism as an ontological belief. However, in terms of relationships between the knower and the known it leans closer to constructivism, since it also advocates subjectivist epistemology. At the same time, critical theory is distant from positivism, criticizing it for objectification of human subjects; and stays far away from constructivist relativism, arguing that social phenomena are a sociohistorical reality that have reified over time. In spite of these ontological and epistemological differences, critical theory to some extent depends on naturalistic and antinaturalistic methodologies, although they are used to attain different goals (Braybrooke 1987; Lakatos and Musgrave, 1970).

Critical theory rejects explanation as a scientific goal. Rather, the goal of critical science is to reveal anti-democratic oppressions, and to liberate humans from prejudices, ignorance, and ideologically frozen conceptions. To achieve these goals, critical theory employs a dialogic/dialectical methodology that attempts to understand the intersubjective meanings, values, and motives of social actors. It attempts to disclose contradictions in social structure caused by hegemony of dominant meanings that are enforced by ideology (Comstock, 1997). Critical theory rejects the positivistic 'objective' picture of social reality and cuts through surface appearances by locating social phenomena in specific historical contexts and by analyzing their inner interrelated relations. Similarly, critical theory goes one step further than constructivism by studying action rather than behavior, and seeking change in addition to interpretation of meanings (Harvey, 1990).

The historical roots of critical theory stem from the works of Aristotle, Plato, Socrates, Machiavelli, Hobbes, Locke, Saint-Simon, Weber, and Marx. The roots of modern critical theory stem from the works of a group of German scholars in the 1920s (Max Horkheimer, Theodor Adorno, Herbert Marcuse) who are commonly referred to as the Frankfurt School. In the 1960s, postulates of the Frankfurt School were radically revised by Jurgen Habermas and Anthony Giddens whose ideas have strongly influenced philosophers and social scientists in many countries including North America (Fay, 1987). Three major contemporary academic journals: Telos, Dissent, and Theory, Culture \& Society, are oriented towards publishing results of critical studies. In the marketing literature, the critical tradition seems weak and appears to be represented mainly by scholars with non-North American ethnic and cultural backgrounds (Monieson, 1988; Wish, Dholakia, and Rose, 1982).

\subsection{Pluralist Paradigm}


There is a perspective in the philosophy of social science that advocates a holistic and pluralist approach to conducting social science. This "multivaried" perspective stems from the arguments of some philosophers who believe that naturalistic, antinaturalistic, and critical theory approaches are compatible, complementary, and legitimate ways of studying social phenomena. They argue that none of these approaches should have a monopolistic hegemony on representing the ultimately correct science. They have to co-exist in a dialogical position of supplementing rather than competing with each other (Braybrooke, 1987; Gultung, 1990; Israel, 1971; Rabinow and Sullivan, 1987).

Israel's (1971, pp. 343-347) discussion of Habermas' (1967) complex philosophy is one of the best available in the English speaking literature for better understanding this pluralist perspective. It is summarized in Figure 1.

Israel interprets Habermas as identifying three types of social scientific ideals: the natural science ideal, the hermeneutic ideal, and the ideal of a critical social science. These three types of scientific ideals have shaped three major research orientations: positivism, structuralism, and critical theory. These three research orientations are stimulated by three different research interests that stimulate production of three different types of knowledge. Positivism produces the informative type of knowledge and is motivated mainly by technical interest; structuralism produces the interpretative type of knowledge and is motivated by hermeneutic/interpretative interest; finally, critical theory produces criticism and is motivated by emancipatory interest. The three types of interests and three types of knowledge are targeted on three main media--work, language, and power--that, according to Habermas, are necessary for the maintenance of a social system (Figure 1). The major premise of the pluralist paradigm is that "all social acts should be understood from three different constituent conditions: language; the basic process of production by which 'nature is transformed;' and social power relations." (Israel, 1971 p. 345, italics from the original).

In broad terms, the pluralist paradigm states that positivism (naturalist) approaches are effective for conducting social science. However, by focusing exclusively on question "What is truth and what is false?" causes this approach to ignore the role of values, which contributes to the conservation of existing social conditions. Therefore, there is a need to supplement this positivistic approach with critical social science, which uncovers and reveals dominant values by analyzing whether or not they are acceptable in the context of a healthy and democratic social system. However, to achieve this goal, critical social science, in its turn, should be accompanied by hermeneutics, which seek a deep and rich understanding of meanings held by social actors and to identify the ways in which these meanings influence their behavior (Gultung, 1990).

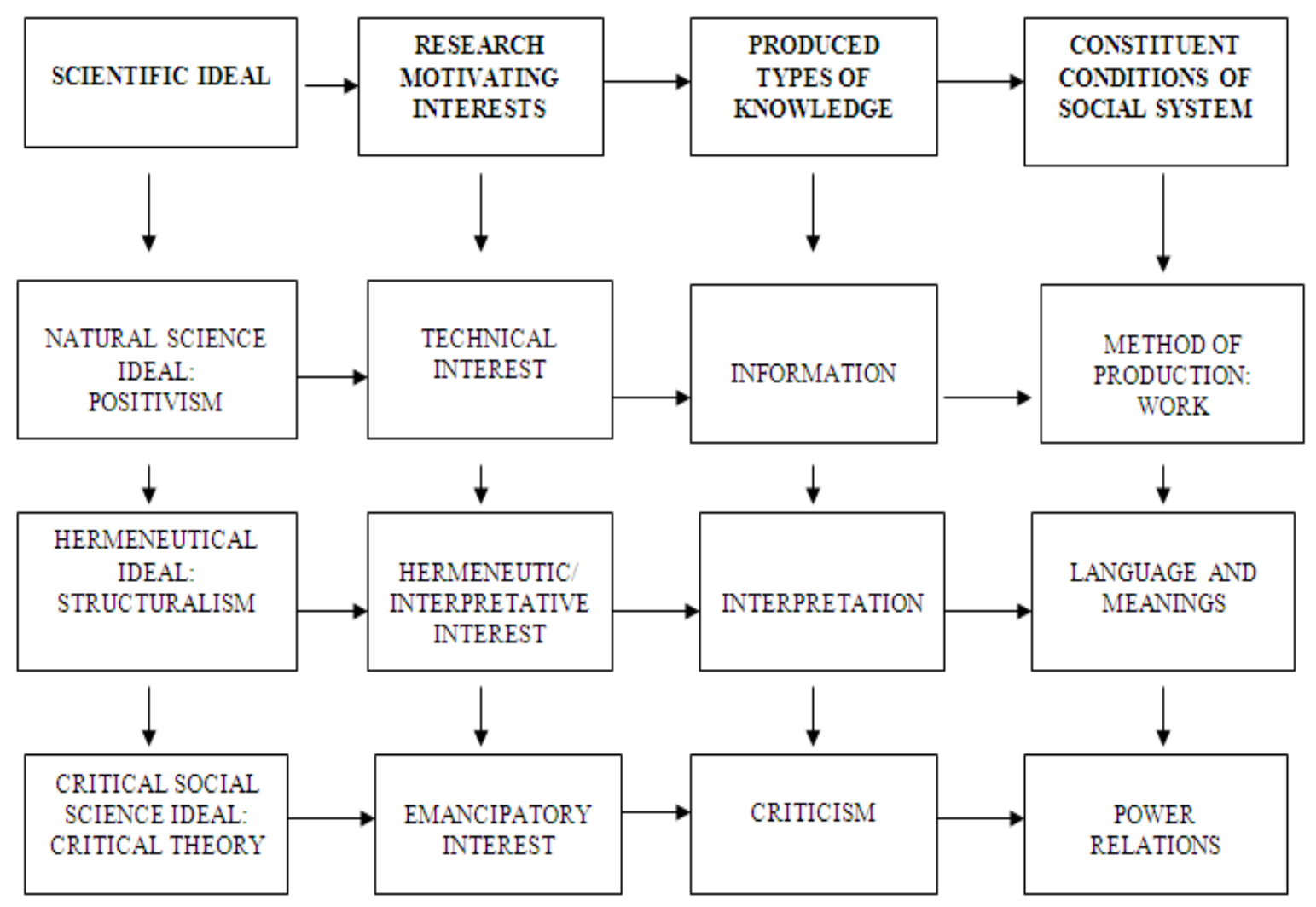

Figure 1. Habermas' Pluralist Paradigm 


\section{The Case of Methodological Development of Nonprofit Marketing Concept}

Walsh's (1994) analysis suggested that interest toward marketing among public administrators was significantly stimulated by the growth of consumerism, the development of market-based approaches to the provision of public services, and by extensive use by government agencies of promotional techniques. Similarly, O'Farcheallaigh (1991) contended that the marketing philosophy in government organizations was a reaction to a commonly recognized need for governments to change the ways in which they organized and delivered public services. One of the earliest attempts to view citizens as customers, city hall as the community's market place, and the city manager as a marketing manager, was a series of articles in a 1970 issue of Public Management published by the International City Management Association (ICMA). Several articles--written by the executive director of a government city center organization, a consultant from an advertising agency, and a professor of government--defined marketing, described its usefulness for government organizations, and suggested that marketing tools could offer innovative ways of addressing issues for public managers (Garvey, 1970; Goldberg, 1970; Joyner, 1970). The general tone of these articles was that marketing was an overlooked opportunity for improving the delivery of city services, and many public sector managers were unaware of the positive role of marketing even though they were unconsciously engaged in it.

Kotler and Murray (1975) introduced marketing as a concept into the more scholarly public administration literature in the leading North American public administration journal. Since that time, the word marketing has become an established term in the public manager's lexicon. However, in the two decades following the Kotler and Murray article, the application of marketing tools to the public sector was confusingly linked with their application to the nonprofit sector. Thus, texts and articles often use as synonyms such terms as nonprofit marketing, government marketing, political marketing, and social marketing even though there are different environmental contexts and, hence, marketing applications in each of these milieus. It appears that public administrators and the literature most commonly use the term "nonprofit marketing." This is probably attributable to the original articulators of the generic marketing concept believing the term "nonprofit organization" to be an appropriate generic term for the public sector and social cause organizations (Kotler and Levy, 1969; Kotler, 1972).

Kotler and Murray (1975) suggested one of the earliest and most influential conceptualizations of public sector marketing. It was elaborated upon in a text published in the same year (Kotler, 1975). Kotler adopted (Kotler and Levy, 1969; Kotler, 1972) definition, and Blau and Scott' s (1962) classification of formal organizations. In Kotler's (1975a, p.
5) interpretation, a formal organization is "a purposeful coalescence of people, materials, and facilities seeking to accomplish some purpose in the outside world." Different purposes determine different types of formal organizations: business concerns seek to benefit their owners: service organizations seek to benefit their clients; mutual benefit organizations seek to benefit their members; and commonweal organizations seek to benefit the public at large. In spite of differences in goals, Kotler contended that all formal organizations were involved in exchange relationships with various categories of publics.

However, the concept of voluntary exchange is only one of several possible philosophical alternatives for explaining the relationships between formal organizations and their publics. Other options include: the love system, characterized by the underlying motive of benevolence on one side without any necessary reciprocation by the other; and the threat system characterized by an underlying motive of malevolence on one side. Thus, in Kotler's interpretation, a church and its members, a police department and citizens, a charity and its donors, and so on: are all engaged in exchange transactions that involve taxes, services, money, contributions, feelings of well-being, or other tangible and intangible benefits. If an organization is willing to exchange resources with an identified public, then this category of public becomes the organization's market or "distinct group of people and/or organizations that have resources which they want to exchange, or might conceivable exchange, for distinct benefits" (Kotler, 1975a, p. 22).

Having introduced the notions of organization, public, market and exchange, Kotler explained the differences between marketing and a sales orientation. The marketing concept involves continuously adjusting the firm's offerings to the targeted customers' needs. In contrast, a sales orientation involves continuous adjustment of buyers' needs to the firm's offerings. He asserts that a sales orientation is likely to be characteristic of an unresponsive organization, while a marketing orientation is likely to result in a highly responsive organization. Kotler (1975a) favors the latter and defines marketing as being applicable for all types of formal organizations:

The analysis, planning, implementation, and control of carefully formulated programs designed to bring about voluntary exchanges of values with target markets for the purpose of achieving organizational objectives. It relies heavily on designing the organization's offering in terms of the target market's needs and desires, and on using effective pricing, communication, and distribution to inform, motivate, and service the markets (p. 5).

Some negative comments towards applying the marketing philosophy and techniques in the public sector have emerged in the public administration literature. Opponents of marketing in the public administration field felt uncomfortable with Kotler's generic transactional conceptualization of public marketing, which suggests no differences between public and private management; public and the nonprofit sectors; and the role and application of 
marketing in these different sectors.

Rainey, Backoff, and Levine (1976) contested Kotler and Murray's (1975) and Murray's (1975) positions that there were only limited differences between formal organizations and between managing public and private entities; that their trends converged; and that as a result, marketing was appropriate in the public sector. In contrast, Rainey et al., (1976) postulated that there are crucial differences between the two sectors and, thus, in the role of marketing in public agencies. Rainey et al., (1976) contended that a public organization: works in an environment with less market exposure; has more legal and formal constraints on its procedures and spheres of operation; relies more on the "coercive" and "monopolistic" nature of many government activities; and has less decision-making autonomy. Allison (1992) and Walsh (1994) reached similar conclusions. These analyses challenged the notions of the appropriateness of both the marketing philosophy and voluntary exchange in the delivery of public services.

Although differences were recognized and incorporated into some conceptualizations of public sector marketing, the controversy remained salient. Crompton and Lamb (1986b), Mokwa and Permut (1981), and Coffman (1986), who all accepted the distinctive positions of commentators on both sides of the debate, demonstrated the centrality of controversy. They recognized Rainey et al.'s (1976) crucial differences between public and private organizations, but they accepted the Kotlerian conceptualization of marketing based on the voluntary exchange paradigm as the basis of their conceptual frameworks.

Doubts were raised that the conceptualization of public sector marketing authentically reflected the public realm (Loveday, 1991; Walsh, 1994). Walsh (1994) and Loveday (1991) argued that public sector marketing as it is operationalized has little in common with the public realm. According to Walsh (1994), marketing has not developed in a fashion that is specific to the context of government. $\mathrm{He}$ believes that the current conceptualization of marketing reflects a simple semantic adjustment of commercial marketing definitions, for example, by dropping the notion of profit without substantive adaptations to the political context of the public realm. Loveday (1991) questions whether public sector marketing is in any way innovative. He argues that "what the marketers claim as their own has been developed by a lot of other people as well; marketers have made a distinctive contribution in thinking it through in the context of selling products, first tangibles and more recently intangibles, to a mass market" (p. 174). Both authors support Walsh's (1994, p. 70) conclusion that there needs to be a rethinking and re-examination of public sector marketing in order to develop its new politically informed form, and to make it "specifically public service marketing rather than a pale imitation of a private sector approach within the public service."

Empirical studies seem to support these critical voices. Graham (1995) found that after 10 years of attempting to implement it in public sector organizations, most agencies still were not customer-oriented as defined by the generic marketing concept. Marketing continued to be perceived by many public administrators as unethical, goal distorting, and as an inappropriate model and framework for public service delivery (Buchanan et al., 1994; Ehling, White, and Grunig, 1992; O'Faircheallaigh et al., 1991; Vanden Heede and Pelican, 1995).

\section{Discussion}

Arndt (1985) suggested that the emergence of the broadening of marketing paradigm, and the consequent emergence of the transactional concept of public sector marketing was attributable to dominance of the naturalist (positivist) research orientation in the marketing literature. Such an approach rests on three major foundations: monism, physicalism, and reductionism. Monism means that all scientific disciplines are part of a higher order discipline. Thus, soft and hard sciences are unified and should use the same hypothetico-deductive method. Physicalism postulates that the same single hypothetico-deductive method practiced by both soft and hard sciences should be accompanied by the same ideals of unified science (e.g. those commonly accepted in physics should be accepted in recreation and parks and in marketing). These ideals are a drive for objectivity, a focus on prediction and control, and a search for eternal, time-space-context-value free, axiomatic, generic, and universal laws. These ideals of unified science give rise to the logic of reductionism which studies human behavior like a physical entity. Behavior is reduced to its parts and these parts are reified--"treated like things manipulable in the experimental laboratory and measured by interval or ordinal scales." (Arndt, 1985 p. 14).

Kotler's (1972) generic concept of marketing; Bagozzi's (1975) typology of marketing exchange; and Hunt's (1976) elaboration of the scope and nature of marketing are major studies in the context of public sector marketing that can be identified as lying between the logico-positivist/empiricist and the hermeneutic/interpretative paradigms. Kotler (1972) used the fundamental theorem of economic exchange, and a neutral approach to business and public sector organizations, to develop the generic concept of marketing expressed in positivistic terms that was defined by four axioms with 15 corollaries. Kotler's perspective was advanced further by Bagozzi (1975) who developed a typology of marketing exchange based upon a deeper understanding and interpretation of exchange processes, using insights drawn from the anthropological and sociological literatures. Hunt (1976) cemented this perspective of marketing as an exchange process by establishing the scope and nature of generic marketing with positive-normative, micro-macro, and profit-nonprofit dimensions. Marketing academia generally accepted and recognized these positivistic intellectual ideas as objective truth, and contended that controversy about the validity of extending the marketing concept to nonprofit and government organizations was over 
(Nickels, 1974; Lovelock and Weinberg, 1978).

Once that widespread acceptance and recognition had been achieved, the next logical steps in the domain of public sector marketing studies should have included: a search for additional empirical support for the concept; further improvement and refinement of public sector marketing theory; additional investigation of the complexities of exchange in the public sector context; and cross comparison of public and private agencies and their managers who accept or reject the marketing concept as part of management actions. However, these follow-up studies have failed to consolidate the ongoing premise. The failure is exemplified by: (1) little empirical evidence emerging during the last two or three decades to support the concept, and a strange reluctance of researchers to engage in such studies (Hirschman, 1986; Monieson, 1988); (2) overwhelming acceptance of the concept among marketing scholars, and explicit rejection of the same concept by a substantial proportion of public administrators (Hunt, 1976; Schultz et al., 1988; Vandeen Heede and Pelican, 1991); and (3) confusion as to the meaning of standard exchange terminology, resulting often in mutually exclusive interpretations of exchange forms and structures (Carman, 1980; Bagozzi, 1975; Pandya and Dholakia, 1992).

These discrepancies suggest that among the three major research approaches discussed above, the logico-positivist/empiricist paradigm is poorly equipped to address the study problem. In accordance with its philosophical tenets, the logico-positivist/empiricist research paradigm would involve searching for empirical data using experimental methodology, rigorous research design, sampling procedures, ordinal or nominal scales, and extensive statistical analysis. In contrast, the hermeneutic/interpretative research paradigm would concentrate on production of knowledge through interpretation, denying objectivity and focusing on developing a deeper understanding of exchange processes within the public sector context.

The current conceptualization of public sector marketing does require extensive qualitative and quantitative empirical testing. During the last three decades, it has flourished in the academic literature without adequate empirical support, according to Monieson (1988). However, results of such studies produce biased results reflecting the expectations of the researcher. Rosenthal (1968) showed in a series of studies that expectations of researchers can bias their research results and his works challenged assumptions about objectivity in the research process. The philosophical literature seems to support this conclusion (Marshall, 1990; Zeller, 1987). This suggests that researchers look for confirmatory or disconfirmatory support for the existing conceptualization of public sector marketing depending on the intellectual traditions of a preferred school of thought. Within the marketing discipline alone, there are twelve schools of thought (Sheth et al., 1988). Public sector marketing embraces the public administration field and within it, there are several schools of thought (e.g. rational choice school, managerialism). The theoretical traditions of a particular school of thought can easily bias the conclusions of a study.

Even though some consensus or parallel can be found between schools of thought in the public administration and marketing fields, there are some methodological difficulties associated with the the logico-positivist/empiricist research orientation. For example, it is likely to be challenging to compare groups of public administrators and marketing practitioners, and to draw conclusions from their responses. This problem is referred to in the social science literature as a Lord's paradox (Levine, 1974). Lord (1967) showed that there were two logically consistent statistical procedures for comparing differences between groups in a selected data set. However, these two procedures when used on the same data set yielded completely opposite conclusions and there were no commonly accepted criteria to guide when to use which method of analysis. As Lord (1967, p. 305) concluded: "The usual research study of this type [analysis of differences between groups] is attempting to answer a question that simply cannot be answered in any rigorous way on the basis of available data".

Kotler and Levy's (1969a), Kotler's (1972), Hunt's (1976), and especially Bagozzi's (1975) studies to some extent reflect hermeneutic tradition, since all of them were intended to offer deeper understanding and interpretation of exchange processes in nonbusiness organizations. However, the explicit axiomatic and lawlike conclusions drawn from these studies clearly separate them from ontological and epistemological assumptions underpinning the hermeneutic tradition. Relatively recent studies targeted on deepening the understanding of exchange processes in social organizations, and which therefore might be considered as being positioned within the hermeneutic perspective, have reached less axiomatic and generic conclusions. Carman's (1980, pp. 12-13) extension of his earlier work (1973) on the universality of marketing recognized that existing conceptualizations of exchange structures in the marketing literature were "confusing" and "controversial." Almost two decades, Kerin (1996, p. 6) used the same word, "controversial," when discussing the marketing broadening proposition and nontraditional applications of marketing. Robin (1978) returned to the original debate on the broadening marketing proposition and tested both Luck's (1969) apologist approach based on the notion of quid pro quo and Bagozzi's (1975) "marketing as exchange" approach against four normative criteria: abstraction, correspondence, pragmatism, and simplicity. He found that that the Bagozzi's approach failed to satisfy all four criteria, while Luck's approach failed to satisfy only one of them. Robin suggested replacing Bagozzi's approach with specific definitions relating to general marketing and social marketing. Pandya and Dholakia (1992) echoed Robin's conclusions and offered an institutional theory of marketing exchange.

These studies suggest that a hermeneutic research orientation designed to interpret public sector marketing 
might be preferable for the future studies. However, there are several arguments that cast doubts on the appropriateness of such a choice. These arguments relate to the general criticism of hermeneutics as a research orientation, rather than to specific studies. First, interpretative type of knowledge has been criticized by both positivists and critical theorists for producing the so-called paradox of the hermeneutic circle that represents an endless process of interpretation (Morrow and Brown, 1994). This paradox stems from epistemological assumptions about relative truth that exclude ultimate and "correct" interpretation, and makes findings from previous interpretative studies tentative since there is no ultimate truth to be found according to the postulates of relativism. Thus, there is a danger that a study that attempts to interpret exchange relationships, and is intended to enhance understanding of public sector marketing, would be lacking in worth and meaning. It would never be known if the results and conclusions of such a study are correct and final.

The second argument for selecting a hermeneutic research orientation stems from the history of hermeneutics itself. The hermeneutics approach still seems loyal to the traditions of the religious exegesis, in which disputed or hidden meanings of authoritative religious texts were interpreted over time without challenging the authoritative position of the text itself. In other words, the interpretation process within the hermeneutics tradition is limited to polishing the sacred text rather than to evaluating its authoritative status. While every new interpretation brings new meanings or replaces disputed or previous ones, the interpretation process maintains the authoritative status quo of the text. Morrow and Brown (1994) refer to this as "post-structuralism" that promises everything but requires no engagement in the polity. For example, most interpretative studies that have attempted to interpret nonprofit marketing and refute the Kotler-Bagozzi-Hunt transactional interpretation of generic and nonprofit marketing, challenge the forms and types of exchange rather than the concept of exchange itself. Pandya and Dholakia's (1992) institutional theory of exchange in marketing, Carman's (1980) paradigms for marketing theory, and Robin's scope of marketing, all offer some form or type of exchange rather than replacing the authoritative notion of exchange itself. As a result, the marketing literature offers numerous forms and types of exchange concepts rather than a conceptual alternative that could have been accepted not only by marketing scholars but also by public administrators. These forms and types of exchange processes are often confusing, controversial, inconsistent, and sometimes even mutually exclusive though all of them are based on almost the same literature sources.

For these reasons, Habermas (1967), who advocated a pluralist approach espoused a major crucial objection to pure reliance on the hermeneutical tradition in approaching the study of social phenomena. Although choice of the pluralist tradition is a plausible option, it is technically more difficult. It would likely require implementation of at least three independent and methodologically different studies, conducted by a team consisting of three researchers with three different types of academic training and philosophical beliefs.

\section{Conclusion}

In the marketing literature the pluralist tradition has been represented by the work of Monieson (1982; 1988), and Arndt (1985) whose philosophical orientation relies heavily on the work of Gutlung (1990). Pluralists seek to break free from the paradigmatic provincialism that they perceive characterizes current marketing science. To achieve this goal, advocates of pluralism suggest that: (1) the dominant naturalist approach in marketing should be diluted by adopting alternative research orientations such as criticism and constructivism (Arndt, 1985; Hirschman, 1986); (2) marketing scholars should practice their right to dissent, to understand, and to be simple (Monieson, 1982); (3) a diverse array of research paradigms to better reflect subjective experiences, values, criticism, and conflicts should be brought into marketing science (Arndt, 1985); and (4) different metaphors within alternative research paradigms (e.g. alienated man, victimized consumers, language and text, experienced man, irrational man, political economies, and the political marketplace) should be recognized by marketing scholars (Arndt, 1981; 1985; Pandya and Dholakia, 1992).

Although their approach has been debated (Hunt, 1983), the voices of pluralists have ignited a philosophical rethinking both of general marketing theory and of the conceptualization of public and non-profit sectors marketing in the context of public and non-profit sectors management (Gummesson, 2002; Hunt, 1994; Walsh, 1994). The main conclusion of this paper is that pluralist methodological approach will benefit and enrich both: the marketing science and non-profit field.

\section{REFERENCES}

[1] Allison, G. T. (1992). Public and private management: Are they fundamentally alike in all unimportant respects? In J. M. Shafritz and A. C. Hyde (Eds.) Classics of public administration (pp. 457-476). Pacific Grove, CA: Brooks/Cole Publishing Company.

[2] Arndt, J. (1978, January). How broad should the marketing concept be? Journal of Marketing, 42(1), 101-103.

[3] Arndt, J. (1981, Fall). The political economy of marketing Systems: Reviving the institutional approach. Journal of Macromarketing, 1(2), 36-47.

[4] Arndt, J. (1985, summer). On making marketing science more scientific: The role of orientations, paradigms, metaphors, and puzzle solving. Journal of Marketing, 49(3), 11-23.

[5] Bagozzi, R. P. (1974, October). Marketing as an organized behavioral System of exchange. Journal of Marketing, 38(2), 77-81. 
[6] Bagozzi, R. P. (1975, October). Marketing as exchange. Journal of Marketing, 39(2), 32-39.

[7] Barach, J. B. (1984, July/August). Applying marketing principles to Social Causes. Business Horizons, 27(4), 65-9.

[8] Bartels, R. (1974, October). The identity Crisis in marketing. Journal of Marketing, 38 (2), 73-76.

[9] Bell, M. L. (1976). The floundering marketing concept. In H. Nash and D. Robin (Eds.) Proceedings: Southern Marketing Association 1976 Conference (pp. 264-266). Mississippi State University: The Southern Marketing Association.

[10] Bell, M. L. and C. W. Emory (1971, October). The faltering marketing concept. Journal of Marketing, 35(2), 32-37.

[11] Beveridge, B. (1995, January 2). Marketing needed in the public Sector. Marketing News, 34.

[12] Blair, E. (1977, January). Letter to the editor. Journal of Marketing, 41(1), 134.

[13] Blau, P., and Scott, D. (1962). Formal organizations. San Francisco, CA: Chandler Publishing Co.

[14] Bleicher, J. (1980). Contemporary hermeneutics. London: Routlege and Kegan Paul.

[15] Bloom, P. N. and Novelli, W. D. (1981, Spring). Problems and Challenges in social marketing. Journal of Marketing, 45(2), 79-88.

[16] Boulding, K. (1973). The economy of love and fear. Belmont, CA: Wadsworth.

[17] Braybrooke, D. (1987). Philosophy of social science. Englewood Cliffs, NJ: Prentice Hall.

[18] Buchanan, D. R., Reddy, S., and Z. Hossain (1994). Social marketing: a Critical appraisal. Health Promotion International, 9(1), 49-57.

[19] Capon, N. (1981, Spring). Marketing strategy differences between state and privately Owned Corporations: An exploratory analysis. Journal of Marketing, 45(2), 11-18.

[20] Capon, N. and Mauser, G. (1982, Summer). A review of nonprofit marketing texts. Journal of Marketing, 46,(3), $125-128$.

[21] Carman, J. M. (1973, Autumn). On the universality of marketing. Journal of Contemporary Business, 2(4), 2-15.

[22] Carman, J. M. (1980). Paradigms for marketing theory. Research in Marketing, 3 Greenwich, CT:JAI Press, 1-36.

[23] Coffman, L. (1986). Public sector marketing: A guide for practitioners. New York: John Wiley and Sons.

[24] Comstock, D. E. (1997). A method for critical research. In M. Martin and L. C. Mclntyre (Eds.) Reading in the philosophy of social science (pp. 234-247). Cambridge, MA: The MIT. Press.

[25] Crompton, J. L. and Lamb, C. H. (1986b). Marketing government and social services. New York: John Wiley and Sons.

[26] Dawson, L. L. (1979). Resolving the Crisis in marketing thought. Management International Review, 19(3), 14-25.

[27] Dixon, D. (1978, Summer). The poverty of Social marketing.
MSU Business Topics, 26, 50-56.

[28] Duhaime, C, McTavish, R. and C A. Ross (1985, Spring). Social marketing: An approach to the third-world development. Journal of Macromarketing. 5(1), 3-12.

[29] Ehling, W. P., White, J., and Granig, J. E. (1992). Public relations and marketing practices. In J. E. Granig (Ed.), Excellence in public relations and Communication management. Hillsdale, N J: Lawrence Erlbaum Associates.

[30] Etgar, M, and Ratchford, B. T. (1975). Marketing management and marketing conflict in nonprofit Organizations. Combined Proceedings, 268-261. Chicago, IL: American Marketing Association.

[31] Fay, B. (1987). Critical social science. Ithaca: N.Y: Cornell University Press.

[32] Ferrell, O. C and Perachione, J. R. (1980). An inquiry into Baggozi's formal theory of marketing exchanges. In Lamb, $\mathrm{C}$ W. and Dunne, P. M. (Eds.) Theoretical development in marketing (pp. 140-156). Chicago, IL: American Marketing Association.

[33] Ferrell, O. C and Zey-Ferrell, (1977, Fall). Is all Social exchange marketing? Journal of the Academy of Marketing Science, 5(4), 307-314.

[34] Feyerabend, P. (1962). Explanation, reduction and empiricism. In H. Heigh and G. Maxwell (Eds.) Minnesota studies in the philosophy of science (pp. 27-43). Minneapolis: University of Minnesota Press.

[35] Fine, S. M. (1990). Social marketing: Promoting Causes of public and nonprofit agencies. Boston, Mass: Allyn and Bacon.

[36] Fischer-Winkelmann and Rock, R. (1977). "Evolutionary" approaches in marketing science. Management International Review, 4, 61-63.

[37] Foldvary, F. (1994). Public goods and private Communities: The market provision of Social Services. Vermont: Edward Elgar Publishing.

[38] Gallagher, K. and Weinberg, C. B. (1991, Fall). Coping with success: New challenges for nonprofit marketing. Sloan Management Review, 3, 27-42

[39] Garvey, J. (1970, February). Step right this way. Public Management, 52(2), 2.

[40] Goldberg, N. (1970, February). Marketing: What it means. Public Management, 52(2), 4-5.

[41] Graham, P. (1995). Are public Sector organizations becoming Customer centered? Marketing Intelligence \& Planning, 13(1), 35-47.

[42] Guba, E. G. and Lincoln, Y. S. (1994). Competing paradigms in qualitative research. In N. Denzin and Y. Lincoln (Eds.). Handbook of Qualitative Methodology (pp. 15-36). Beverly Hills, C A: Sage Publications.

[43] Gummesson E. (2002) «Qualitative Research in Marketing: Roadmap for a Wilderness of Complexity and Unpredictability», European Journal of Marketing. 36(3), pp. 325-349.

[44] Gultung, J. (1990). Theory formation in social research: A plea for pluralism. In E. Oyen (Ed.), Comparative 
methodology: Theory and practice in international social research (pp. 96-112). London: Sage Publications.

[45] Habermas, J. (1967). Theorie and praxis. [Theory and Practice] Neuwied: Luchterhand Verlag.

[46] Harvey, L. (1990). Critical social research. London: Unwin Hyman.

[47] Hastings, G. and Haywood, A. (1991). Social marketing and communication in health promotion Health Promotion International, 6(2), 135-145.

[48] Hirschman, E. C. (1986, August). Humanistic inquiry in marketing research: Philosophy, method, and criteria, Journal of Marketing Research, XXIII(3), 237-249.

[49] Huff, D. (1954). How to lie with statistics. New York: Norton.

[50] Hunt, S. D. (1976, July). The nature and Scope of marketing. Journal of Marketing, 40(3), 17-28.

[51] Hunt, S. D. (1983, Fall). General theories and the fundamental explanada of marketing. Journal of Marketing, 47(4), 9-17.

[52] Hunt, S. D. (1994). On rethinking marketing: Our discipline, our practice, our methods. European Journal of Marketing, 28(3), 13-25.

[53] Hutton, J. G. (1996). Integrated marketing communications and the evolution of marketing thought. Journal of Business Research, 37(2), 155-162.

[55] Israel, J. (1971). Alienation: From Marx to modern sociology. Boston: MA: Allyn \& Bacon.

[56] Joyner, C. (1970, February). Marketing city services: Overlooked opportunity. Public Management, 52(2), 7-9.

[57] Kahane, H. (1973). Logic and philosophy. (2d ed.) Wadsworth, C A: Belmont.

[58] Kerin, R. A. (1996, January). The pursuit of an ideal: The editorial and literary history of the Journal of Marketing. Journal of Marketing, 60.

[59] Kidder, L. H. (1981). Qualitative research and quasi-experimental frameworks. In M. B. Brewer and B. E. Collins (Eds.), Scientific inquiry and the Social Sciences (pp. 123-145). San Francisco, CA: Jossey-Bass.

[60] Kikert, W. (1997, Winter). Public governance in the Netherlands: An alternative to Anglo-American "managerialism." Public Administration, 75(4). 731-752.

[61] Kotler, P. (1972, April). A generic Concept of marketing. Journal of Marketing, 36(2\% 46-54.

[62] Kotler, P. (1973). Defining limits of marketing. In B. W. Becker, and H. Becker (Eds.) Combined proceedings 1972 (pp. 48-56). Chicago, IL: American Marketing Association,

[63] Kotler, P. (1975a). Marketing for nonprofit Organizations. Englewood Cliffs, NJ: Prentice Hall.

[64] Kotler, P. (1975b). Overview of political Candidate marketing. Advances in Consumer Research ${ }^{\wedge}$ 2, 761-769.

[65] Kotler, P. (1979, January). Strategies for introducing marketing into nonprofit organizations. Journal of Marketing, 43. 37-44.

[66] Kotler, P., and Levy, S. J. (1969a, January). Broadening the Concept of marketing. Journal of Marketing, 33(1), 10-15.

[67] Kotler, P., and Levy, S. J. (1969b, July). A new form of marketing myopia: Rejoinder to professor Luck. Journal of Marketing, 33(3), 55-57.

[68] Kotler, P., and Mindag, W. (1978, October). Marketing and public relations: Should they be partners or rivals? Journal of Marketing, 42(4), 13-20.

[69] Kotler, P. and Murray, M. (1975, September/October). Third sector management: The role of marketing. Public Administration Review, 35(5), 467-72.

[70] Kotler, P. and Roberto, E. (1989/ Social marketing: Strategies for changing public behavior. New York: The Free Press.

[71] Kotler, P. and Zaltman, G. (1971, July). Social marketing: An approach to planned social Change. Journal of Marketing, 35(1), 3-12.

[72] Lakatos, T. and Musgrave, A. (1970) Criticism and the growth of knowledge. Cambridge, Mass: Cambridge University Press.

[73] Lamb, C (1987, July/August). Public Sector marketing is different. Business Horizons, 30(4), 56-60.

[74] Laszniak, G. R., Lusch, R. F. and P. E. Murphy (1979, Spring). Social marketing: its ethical dimensions. Journal of Marketing, 43(2), 29-36.

[75] Lauffer, A. (1984). Strategic marketing for not-for-profit Organizations. New York: The Free Press.

[76] Lazer, W. and Kelley, E. (1973). Social marketing: Perspectives and Viewpoints. Homewood. IL.: Richard D. Irwin.

[77] Leathar, D. S. and Hastings, G. B. (1987, Fall). Social marketing and health education. Journal of Services Marketing, 1(2), 49-52.

[78] Levine, M. (1974). Scientific method and the adversary model: Some preliminary thoughts. American Psychologist, 29(9), 661-677.

[79] Levy, S. J., and Kotler, P. (1969, Winter). Beyond marketing the furthering concept. California Management Review, 12, $67-73$.

[80] Lincoln, Y. S. and Guba, E. G. (1985). Naturalistic inquiry. Newbury Park, CA: Sage Publications.

[81] Little, D. (1991). Varieties of social explanation. Boulder, CO: Westview.

[82] Lord, F. M. (1967). A paradox in the interpretation of group comparisons. Psychological Bulletin, 68(1), 304-305.

[83] Loveday, P. (1991). Public sector marketing: A critical appraisal. In O'Fairchellaigh, C, Graham, P., and Warburton, J. (Eds.), Service delivery and public Sector marketing (pp. 173-177). Sydney: Macmillan\& Co

[84] Lovelock, C H., and Weinberg, C. B. (1978). Public and nonprofit marketing comes of age. In G. Zaltman and T. Bonoma (Eds.), Review of Marketing 1978 (pp. 413-452). 
Chicago, IL: American Marketing Association.

[85] Lovelock, C H., and Weinberg, C. B. (1984). Marketing for public and nonprofit managers. New York: John Wiley.

[86] Luck, D. (1969, July). Broadening the Concept of marketing Too Far. Journal of Marketing, 33(3), 53-55.

[87] Luck, D. (1974, October). Social marketing: Confusion compounded. Journal of Marketing, 38(4), 70-72.

[88] Manoff, R. K. (1985). Social marketing: New imperative for public health. New York: Praeger Publishers.

[89] Mansfield, H (2011). Social Media for Social Good: A How-to Guide for Nonprofits. McGraw-Hill.

[90] Marshall, C. (1990). Goodness criteria: Are they judgments calls? In N. Denzin and Y. Lincoln (Eds.). Handbook of qualitative methodology (pp. 236-245). Beverly Hills, CA: Sage Publications.

[91] Martin, M. and Mclntyre, L. C. (1997). Reading in the philosophy of social science. (3rd ed.) Cambridge, Mass: The MIT Press.

[92] Mauser, G. A. (1983). Political marketing. New York: Praeger Publishers.

[93] Maxwell (1996). Qualitative research design: An interactive approach. London: Sage Publications.

[94] McCort, D. J. (1994, Spring). A framework for evaluating the relational extent of a relationship marketing strategy: The Case of nonprofit Organizations. Journal of Direct Marketing, 8(2\53-59.

[95] Miles, M. B. and Huberman, A. M. (1996). Qualitative data analysis: An expanded Sourcebook (2nd ed.), Thousand Oaks, CA: Sage Publications.

[96] Miller K.L. (2013) Content Marketing for Nonprofits: A Communications Map for Engaging Your Community, Becoming a Favorite Cause, and Raising More Money. The Jossey-Bass Nonprofit Guidebook Series. San Francisco, CA: Jossey-Bass

[97] Mokwa, M. P., Dawson, W. M. and E. A. Prieve (1980). Marketing the arts. New York: Praeger Publishers.

[98] Mokwa, M. P. and S. E. Permut (1981). Government marketing: Theory and practice. New York: Praeger Publishers.

[99] Morrow, R. A. and Brown, D. D. (1994). Critical theory and methodology. London: Sage Publications.

[100] Monieson, D. D. (1982, Spring). What constitutes usable knowledge in macromarketing? Journal of Macromarketing, 2(1), 14-22.

[101] Monieson, D. D. (1988, Fall). Intellectualization in macromarketing: A world disenchanted. Journal of Macromarketing, 8(2), 24-36.

[102] Murray, M. A. (1975, July/August). Comparing public and private management: An exploratory essay. Public Administration Review, 35(4), 364-371.

[103] Nickels, W. G. (1974, Winter). Conceptual Conflicts in marketing, Journal of Economics and Business, 27(1), 140-3.

[104] Nine, T. (1994). Comments on extending the domain of the marketing discipline. In Houston, F. G. (Ed.), Marketing exchange relationships, transactions, and their media (pp. 14-27). Westport, CT: Quorum Books.

[105] Octen, C. M. (1983). A re-examination of marketing for British nonprofit Organizations. European Journal of Marketing, 17(5), 33-43

[106] O'Fairchellaigh, C, Graham, P., and Warburton, J. (1991), Service delivery and public Sector marketing, Sydney: Macmillan\& Co.

[107] Pandya, A. and Dholakia, N. (1992). An institutional theory of exchange in marketing, European Journal of Marketing, 26(12), 19-41.

[108] Patton, M. Q. (1990). Qualitative evaluation and research methods. (2nd ed.). Newbury Park, CA: Sage Publications.

[109] Rabinow, P and Sullivan, W. (1987). Interpretive social science: A second look. Berkeley: University of California Press.

[110] Rados, D. L. (1981). Marketing for nonprofit Organizations. Boston, MA: Auburn House.

[111] Rainey, H. G., Backoff, R. W. and C. H. Levine (1976, March/April). Comparing Public and private Organizations. Public Administration Review, 36(2), 233-244.

[112] Roberto, E. (1991). Applying a marketing model in the public sector. In O'Fairchellaigh, C, Graham, P., and Warburton, J. (1991), Service delivery and public Sector marketing, Sydney: Macmillan\& Co. (pp. 127-134).

[113] Robin, D. E. (1978, Summer). A useful Scope of marketing. Journal of the Academy of Marketing Science, 6(3), 228-238.

[114] Rosenthal, R. (1968) Experimenter expectancy and the reassuring nature of the null hypothesis decision procedure. Psychological Bulletin, 70(6), 30-47.

[115] Rule, J. B. (1998, Winter). Markets, in their place. Dissent, 5(1). 31-35.Sahlins, M. (1972). Stone Age economics, Chicago, IL: Aldin Atherton.

[116] Shapiro, B. (1973, September/October). Marketing for nonprofit Organizations. Harvard Business Review, 51(5), 123-132.

[117] Sheth, J. N., Gardner, D. M., and Garrett, D. E. (1988). Marketing theory: Evolution and evaluation. New York: John Wiley \& Sons.

[118] Smith, G. (1988). Applying marketing to the public Sector: The Case of local authority leisure Centers. International Journal of Public Sector Management, 1(3), 36-45.

[119] Smith, L. M. (1992). Biographical method. In N. K. Denzinand Y. S. Lincoln (Eds.). Handbook of qualitative research (pp. 286-306). Thousands Oaks: Sage Publications.

[120] Tam, H. (1994). Marketing Competition and the public Sector: Key trends and Issues. New York: Longman.

[121] Toulmin, S. (1972). Human understanding. Princeton: Princeton University Press.

[122] Tucker, W. T. (1974, April). Future directions in marketing theory. Journal of Marketing, 38(2), 30-35.

[123] Vanden Heede, A., and Pelican, S. (1995). Reflections on 
marketing as an appropriate model for nutrition education. Journal of Nutrition Education, 27(3), 141-150.

[124] Wainwright, D. (1997, July). Can sociological research be qualitative, critical and valid? [69 paragraphs]. The Qualitative Report [On-line serial], 3(2). Available: http://www.nova.edu/ssss/QR/QR3-2/wain.html

[125] Walsh, K. (1994). Marketing and public Sector management. European Journal of Marketing, 28(3), 63-71.

[126] Wish, J. R, Dholakia, N. and Rose, S. (1982, Fall). When Dr.
Marx read Dr. Kotler: a dialectical look at American marketing. 1982 Marcomarketing Seminar abstracts. Journal of Macromarketing, 2(2), 85 .

[127] Zaltman, G. and Sternthal, B. (1975). Broadening the Concept of Consumer behavior. Chicago: The Association for Consumer Research.

[128] Zeller, N. (1987) A rhetoric for naturalistic inquiry. Doctoral dissertation. The School of Education. Indiana University, Bloomigton. 